
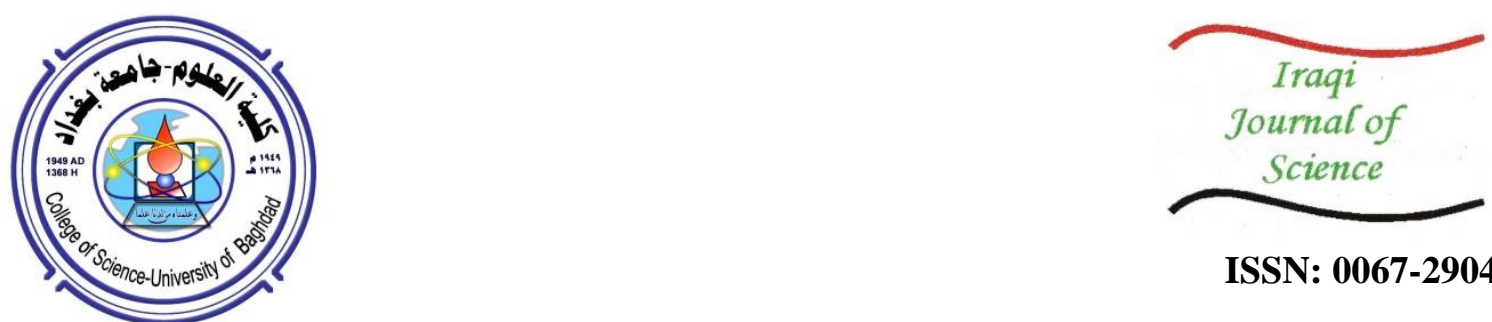

ISSN: 0067-2904

\title{
Impact of Gercus Formation Erosion and Rock Sliding on Duhok Dam Reservoir - Northern Iraq
}

\author{
Sahad Ali Al-Talib ${ }^{1}$, Azealdeen Salih Al-Jawadi*2, Abdul Sattar A. Al-Sanjari ${ }^{1}$ \\ ${ }^{1}$ College of Environmental Science and Technology - Mosul University \\ ${ }^{2}$ Dams and Water Resources Research Center - Mosul University
}

Received: $1 / 5 / 2020$

Accepted: $25 / 8 / 2020$

\begin{abstract}
The environmental impact was illustrated by rockslide and erosion on the Duhok Dam and its reservoir. The evaluation of the geotechnical characteristics of the Gercus Formation was conducted. The research plan was divided into three phases, field, laboratory, and office works. The fieldwork included studying all the geological phenomena of the region related to the environmental impact. The laboratory work focused on studying the geotechnical properties of the various rock samples taken from the Gercus Formation. Rocklab program was used to define the geotechnical properties of a rock mass. The results indicated the weak resistance of the Gercus Formation rocks to weathering and erosion processes, as well as their weak resistance to sliding. These results indicate a kind of risk for this formation on the stability of the dam, as well as its effect on the size of the reservoir storage, due to erosion and deposition of huge amounts of sediments in the dam reservoir.
\end{abstract}

Key words: Duhok City, Dam, Geotechnical Characteristics, Environment, Rock erosion, Rockslide

$$
\begin{aligned}
& \text { تأثير التآكل وانزلاق صخور تكوين جيركس على سد دهوك - شمال العراق }
\end{aligned}
$$

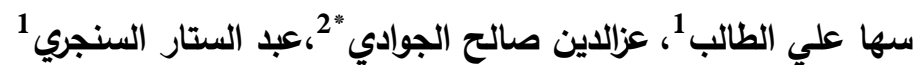

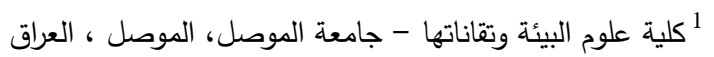

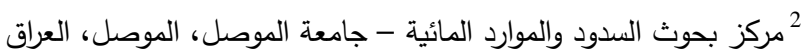

$$
\begin{aligned}
& \text { تم توضيح الأثر البيئي من خلال الانزلاق الصخري وتآكل الصخور على سد دهوك وخزانه. تم تقييم } \\
& \text { الخصائص الجيوتقنية لتكوين جيركس. تم تقسيم العمل إلى ثلاث مراحل، العمل الحقلي، والعمل المختبري، } \\
& \text { والعمل المكتبي. تضمن العمل الميداني دراسة جميع الظواهر الجيولوجية في المنطقة المتعلقة بالتأثير البيئي. } \\
& \text { ركز العمل المختبري على دراسة الخصائص الجيوتقنية لعينات الصخور المختلفة المأخوذة من تكوين }
\end{aligned}
$$

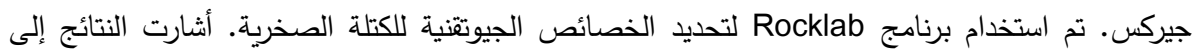

$$
\begin{aligned}
& \text { المقاومة الضعيفة لصخور تكوين جيركس لعمليات التجوية والتآكل، وكذلك مقاومتها الضعيفة للانزلاق. تثير } \\
& \text { هذه النتائج إلى نوع من المخاطر لهذا التكوين على استقرار السد، وكذلك تأثيره على حجم تخزين الخزان، } \\
& \text { بسبب التآكل وترسب كميات كبيرة من الرواسب في خزان السد. }
\end{aligned}
$$

\section{Introduction}

Duhok City is located between two anticlines along the stream valley that comes from the north, 
and it has an undulating topography, ranging from approximately 502 meters in the south and 724 meters above the MSL in the north. The northern border of the city is the Baikher anticline and the southern is Duhok and Zawa anticline (Fig. 1). The city is situated on a syncline of hilly topography, sometimes gentle and frequently high slopes among the above-mentioned anticlines. The small reservoir was established by the earth-fill Duhok Dam at the north of the city.

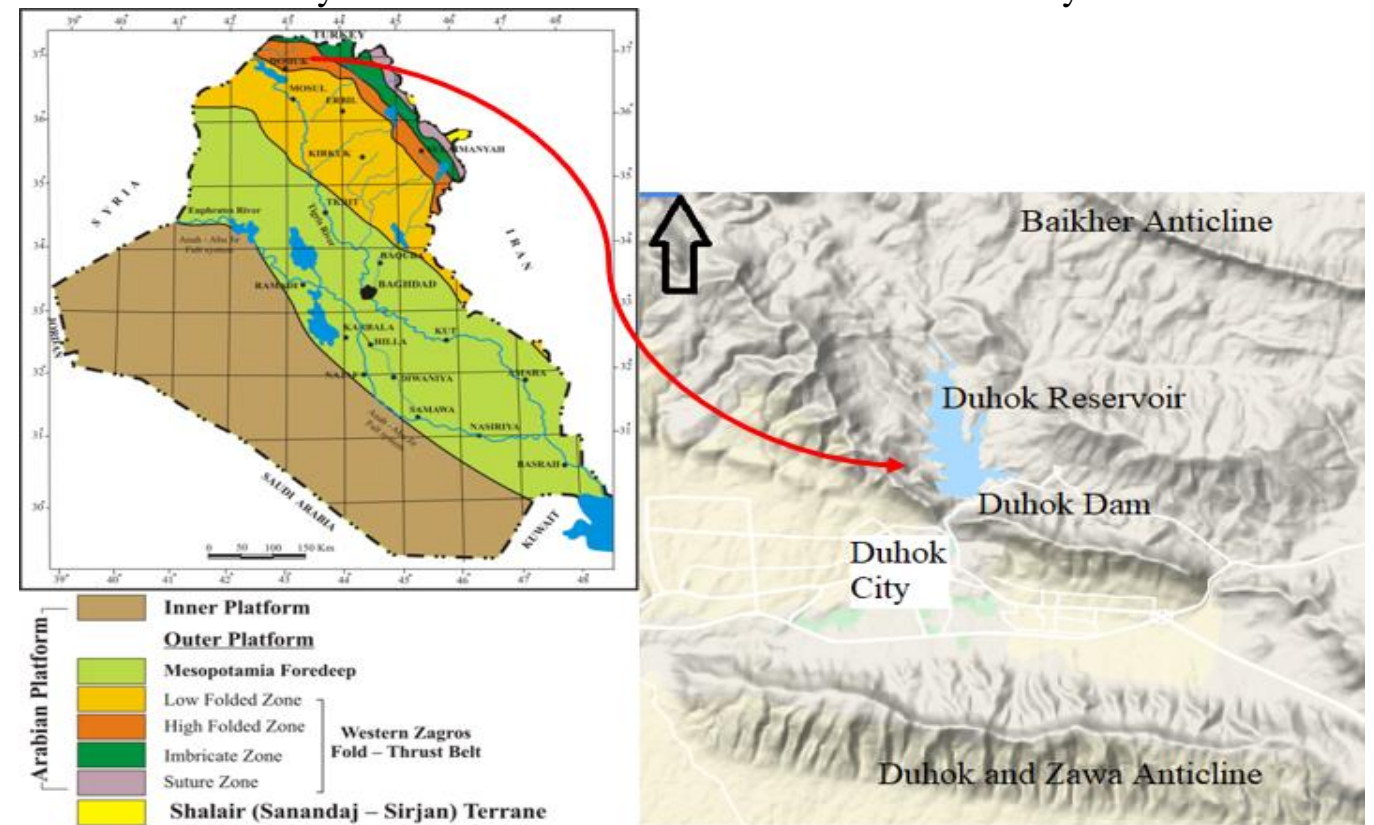

Figure 1- Location maps of the study area located in a tectonic map of Iraq [1].

Many environmental conditions have a negative or positive impact on the stability of any engineering project. The topographical, hydrological, and geological environments are important for the success of any dam project [2]. One of the most significant problems of dam engineering, that determines the life of the dam, is the sediments moving into the dam reservoir. Depending on the amount of sediment reached, the survival of any dam reservoir requires some deterrence [3]. However, in dam and reservoir studies it is important to determine the erosion rate and the amount of sediments generated in the reservoir from the stream and the watershed [4]. On the Pila Spi Formation (Middle to Late Eocene), the Duhok Dam was constructed close to its contact with the Gercus Formation (Middle Eocene) (Fig. 2). The dam and reservoir specifications include $60.5 \mathrm{~m}$ hight, $740 \mathrm{~m}$ length of the crest, and $9 \mathrm{~m}$ width. The dam was constructed in 1988 across the Duhok gully about two kilometers north of Duhok City. The capacity of the reservoir is 52 million $\mathrm{m}^{3}$ with a total area between $1.670 .000 \mathrm{~m}^{2}$ and $2.800 .000 \mathrm{~m}^{2}$.

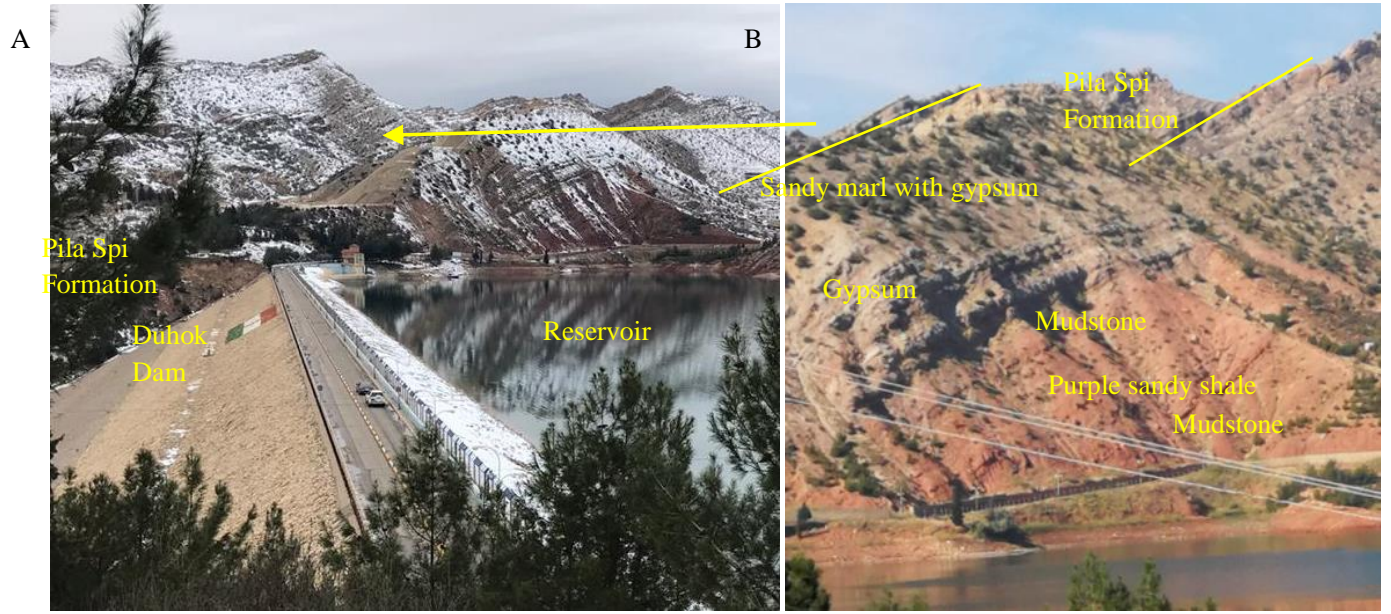

Figure 2- The study area, A: dam site close to the contact between Gercus and Pila Spi formations, with ice in the winter season, B: the geological succession of the study area showing different types of rocks for Gercus Formation. 
Duhok Dam Reservoir is situated on the rocky slopes of the Gercus Formation that surround the reservoir from all directions on the edges. The erosion of the Gercus Formation is a major environmental hazard to dam stability and the quantity and quality of the water in the dam reservoir. The rock fragments are eroded and degraded due to the flowing of rains water, ice, and wind which cause erosion [5] [6]. Gercus Formation rocks are eroded by several fundamental factors that have varying degrees of impacts, the most severe of which are rain, followed by freezing, wind, and earthquakes. The weather is cold, rainy, and frozen from time to time in northern Iraq (Fig. 2A), while it is dry and hot in the summer (Fig. 2B), indicating that the Mediterranean climate is prevailing. The reservoir has an imperceptible effect on the climate of the city.

The main purpose of this research is to demonstrate the effects of weathering and erodes of Gercus Formation on the dam and the reservoir in terms of the sediment volume that flows to the edge of the reservoir. The rocks in this formation are characterized by loose and friable rocks, which make weathering and erosion easier. Therefore, the design of structures on or below the ground surface must consider weathering or the shift in geotechnical properties overtime during the lifetime of an engineering building [5].

\section{Geological setting}

Gercus Formation is consisting of red and purple shale, mudstones, sandy marl with gypsum beds. Also, the area represents the supplementary type section of the formation. The total thickness of the formation in the section of the study area is about 94 meters, underling about $60 \mathrm{~m}$ of Pila Spi Formation that represents the foundation of the dam (Fig. 2A). The Pila Spi Formation forms distinctive ridges of well-bedded hard limestone between the friable Gercus and Fat'ha formations [9]. From the bottom, the detailed thickness of the exposed Gercus Formation is 32 meters of mudstone, 6 meters of purple sand shale, 16 meters of mudstone, 19 meters of gypsum, and 21 meters of sandy marl with gypsum lenses (Fig. 2B).

Gercus Formation is characterized by incipient discontinuities that increase the weathering and erosion impact on ground materials. Weathering starts with the effect of different spheres on the rocks, which causes disintegration, dissolution, and changes in mineralogy leading to the formation of soil. This is followed by the second process, i.e. erosion, by moving weathered materials to the lake or sea by gravity, water, wind, and glaciers [6].

Tectonically, the study area is located within the High Folded Zone close to the boundary with the Low Folded Zone (Fig. 1) [1]. Geologically, successive carbonate formations with clastic formations containing marl, shale, and sand (Fig. 2B) are present in the study area [7].

A tectonic event occurred during the period of study, represented by the occurrence of an earthquake in Turkey, which contributed to the falling of purple sandy shale rock pieces from the slope (Fig. 3). This event was located on or near the plate boundary between the Arabian Plate, Eurasian Plate, and Anatolian Block. The earthquake occurred in eastern Turkey on January 24, 2020, at 20:55:14 local time, at a depth of $11.9 \mathrm{~km}$, and a magnitude of $6.7,377 \mathrm{~km}$ from the city of Duhok in the ENE Doganyol region identified by the coordinates $38.390^{\circ} \mathrm{N} 39.081^{\circ} \mathrm{E}[8]$.

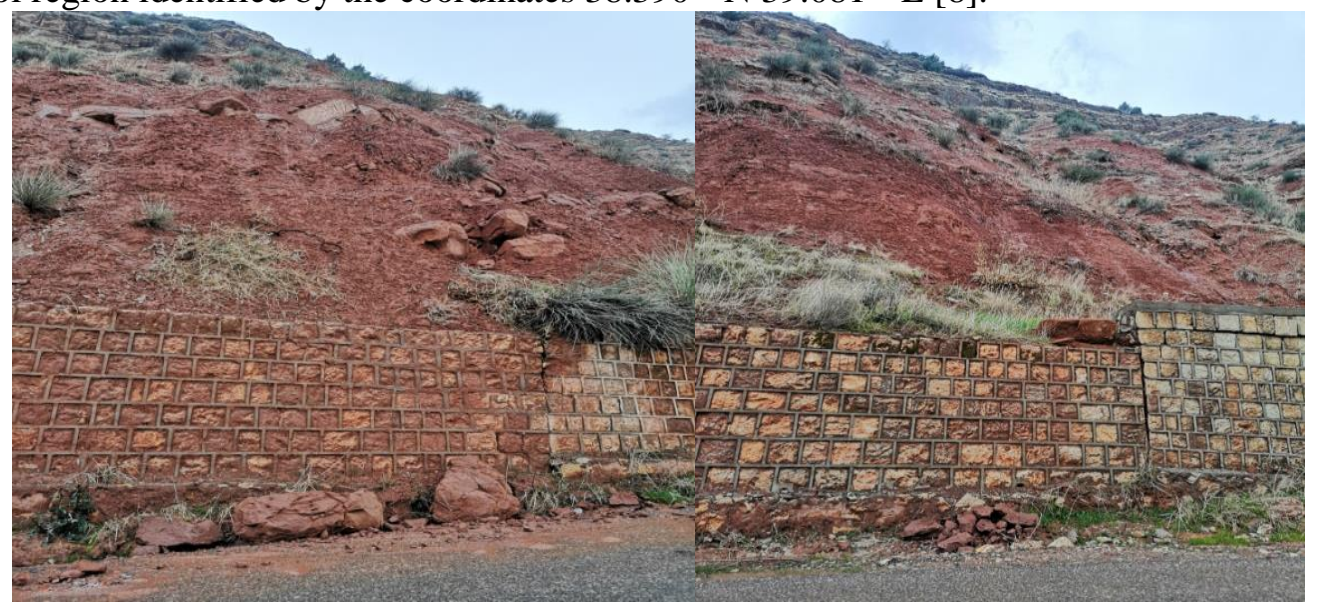

Figure 3-The lithology of the Gercus Formation showing the rockfall of purple sandy shale due to the earthquake of Turkey [8], which contributed to the erosion of disintegrated mudstone by the rains. 


\section{Methodology}

Three stages were carried out in the present work: field, laboratory, and office work, which sometimes overlapped each other.

Fieldwork: The fieldwork was carried out on the Duhok Dam area and the sides of the reservoir as a reconnaissance survey where several locations were chosen for detailed surveys. One of the most important sites is the site near the west side of the dam that is the highest and the nearest to the dam body. The height, slope inclination, and the thickness of each bed were measured whereas samples from these rock beds were collected. A detailed geotechnical survey was used for each layer of rocks, represented by the determination of the rock type, strength, discontinuity attitude, number of sets, spacing, amount of aperture, filling materials, persistence, roughness, waveness, and degree of weathering [10-13].

Laboratory work: In the geotechnical laboratory of the Dams and Water Resources Research Centre, the University of Mosul, a tiltmeter was designed and implemented (Fig. 4). Regular shapes of rock specimens were prepared in standard cubic $(5 \mathrm{~cm})$ edge length and cylindrical $(5 \mathrm{~cm})$ diameter and height [14]. These specimens were broken along the structural discontinuities and then the top piece was weighted. The bottom part was fixed by a snap to the device and the upper part was then placed on it. The part of the device was tilted slowly until the slipping occurred was measured by the degree of tilt, and the procedure was repeated ten times. Moreover, the detection of fundamental friction angles of planar rock discontinuities was performed with different devices, which differ in some characteristics, but consist essentially of a rigid plane rotatable around an axis [14]. However, with non-flat discontinuities, this technique can thus surpass planar cuts in the friction angle.

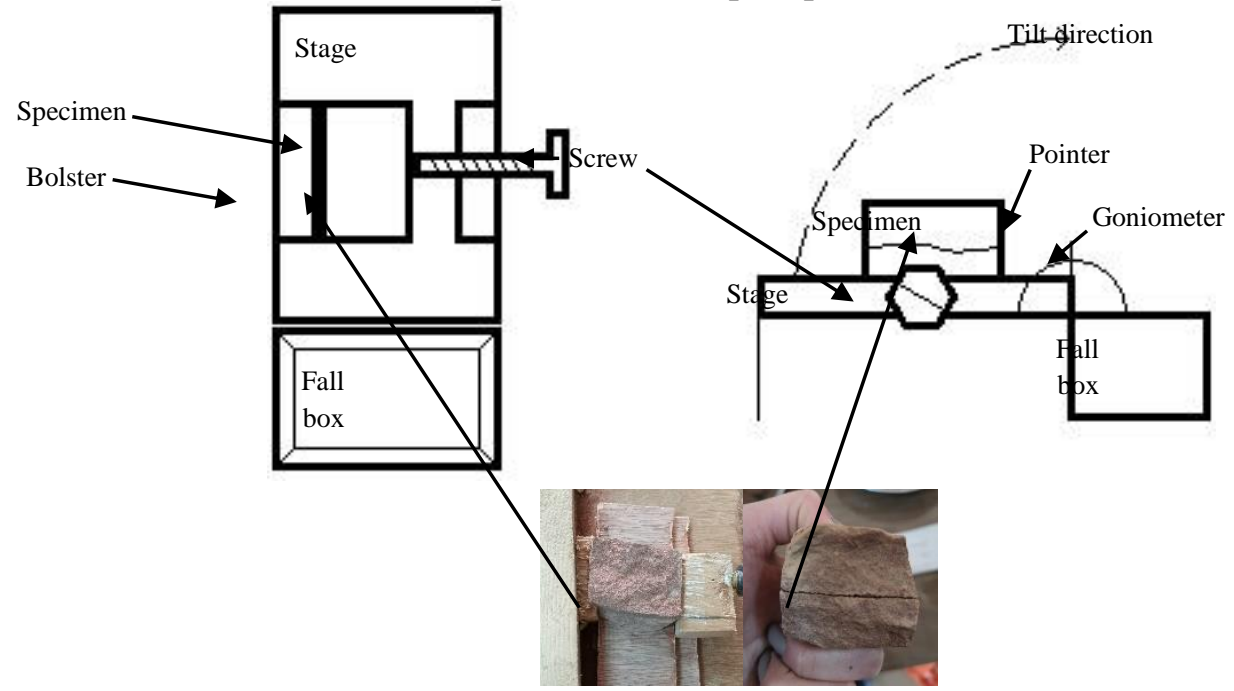

Figure 4- Schematic plan of the designed tilting apparatus; top view at the left and side view at the right. The photos show the shape of a broken sample at the left and the surface of a fixed bottom piece at the right.

The uniaxial compressive strength, wet and dry bulk density, and porosity were determined according to the regular specimen shape and weight $[15,16]$. The clastic rock samples were wetted in water for 48 hours during laboratory tests and disintegrated for sieve analyses and hydrometer tests. Finally, the three different lithological specimens, i.e. sandy shale, mudstone, and sandy marl were slaked by the slake durability apparatus.

Office work: The Roclab software $[17,18]$ was used to process data obtained from comprehensive field surveys and laboratory tests that were collected to assess the rock strength and to determine the rock mass parameters.

Results and discussion

Information obtained from field survey and laboratory investigations were used for the engineering characteristics of the rock masses (Table 1) using the Roclab software. 
Table 1-Rock mass characteristics from field and laboratory parameters analyzed by Roclab

\begin{tabular}{|c|c|c|c|c|}
\hline Characteristics & \multicolumn{4}{|c|}{ Rock type } \\
\hline Hoek-Brown Classification & $\begin{array}{c}\text { Purple sandy } \\
\text { Shale }\end{array}$ & Mudstone & $\begin{array}{c}\text { Sandy } \\
\text { Marl }\end{array}$ & Gypsum \\
\hline $\begin{array}{c}\text { Intact Uniaxial Compressive Strength }\left(\sigma_{\mathrm{ci}}\right) \\
\text { MPa }\end{array}$ & 15 & 45 & 25 & 15 \\
\hline GSI & 22 & 39 & 34 & 66 \\
\hline Disturbance Factor & 0.8 & 0.7 & 0.6 & 0.5 \\
\hline Intact Modulus (E MPa $_{\text {Modulus Ratio (MR) }}$ & 3750 & 11250 & 4375 & 5250 \\
\hline Hoek-Brown Criterion & 250 & 250 & 175 & 350 \\
\hline mb & $\begin{array}{c}\text { Purple sandy } \\
\text { Shale }\end{array}$ & Mudstone & $\begin{array}{c}\text { Sandy } \\
\text { Marl }\end{array}$ & Gypsum \\
\hline a & 0.039 & 0.14 & 0.241 & 1.981 \\
\hline Mohr-Coulomb Fit & 0.00000737 & 0.0001 & 0.0001 & 0.0107 \\
\hline Cohesion MPa & 0.583 & 0.512 & 0.517 & 0.502 \\
\hline Friction Angle & Purple sandy & Mudstone & $\begin{array}{c}\text { Sandy } \\
\text { Marl }\end{array}$ & Gypsum \\
\hline Shale & 0.052 & 0.205 & 0.171 & 0.405 \\
\hline Tensile Strength MPa & 12.42 & 28.91 & 29 & 42.51 \\
\hline Mass Parameters & Purple sandy & Mudstone & $\begin{array}{c}\text { Sandy } \\
\text { Marl }\end{array}$ & Gypsum \\
\hline Shale & -0.003 & -0.046 & -0.011 & -0.081 \\
\hline Global Strength MPa & 0.026 & 0.486 & 0.219 & 1.542 \\
\hline Deformation Modulus MPa & 0.292 & 2.108 & 1.49 & 3.007 \\
\hline & 98.63 & 619.73 & 209.56 & 1939.72 \\
\hline
\end{tabular}

The shear strength (Table-2) was determined using the tilt method by calculating the slip angle for the mass movement of the specified weight in addition to its slip on the fixed block, referred to as the slip area, which is already known, where equation 1 was used. In figure (5), the theoretical background of this equation is defined by the shear strength on the surface of the contact between the two sides of sample $A$, along with the impact of the weight $W$ and the effect of the gravity, where inclination $\varphi$ leads to analyze the force $\tau$. Two components were analyzed, one is perpendicular to the surface of the specimen (normal stress $\sigma_{n}$ ) and the other is the parallel component (shear stress $\tau$ ). Rock mass characteristics are taken into consideration in Equation 2 [19] to predict the shear strength and fit the experimental data [20].

$$
\begin{gathered}
\tau=W / A \tan \varphi+c \\
\tau=\sigma_{n} \tan \left(J R C \log _{10}\left(J C S / \sigma_{n}\right)+\varphi\right)
\end{gathered}
$$

Determination of shear strength $\tau$ was achieved using Hoek-Brown classification parameters (Table 1), the JRC joint roughness coefficient, and the JCS joint wall compressive strength. The results also reflect the differences between intact rock characteristics and the rock mass. Discontinuities normally originate as a natural feature in rock masses, which are generally rough or usually with irregular roughness [21]. When the block slides, the normal stress is low, because the weight of the slide block results in lower stress not exceeding 0.001 Mpa [22]. The natural surfaces of discontinuities have been naturally slake so that they have low shear strength. The disparity in shear strength values can be due to the high angle of inclination, that is observed by the tilting method, and to the mineralogy of the rocks [23]. The mean shear strength result of Equation 2, which is attributable to the high value of normal stresses $\sigma_{\mathrm{n}}$, showed values greater than those of equation 1 (Table 2). The high shear strength of gypsum rock depends on the type of this rock and the absence of the clay minerals [6] which constitute an essential component of the other types, as presented in Table 2. The weathering of the discontinuity wall, the solution impacts, and the formation or alteration of the infill material will reduce these values [6]. The shear strength value derived from equation 2 does not take into consideration the effect of marl and clay filling materials. The filling materials are present in these rocks from the origin, along with those produced from weathering operations. Consequently, the shear 
strength is weak, while the degree of saturation in rainy seasons, in particular, reduces the shear strength by about 50 percent.

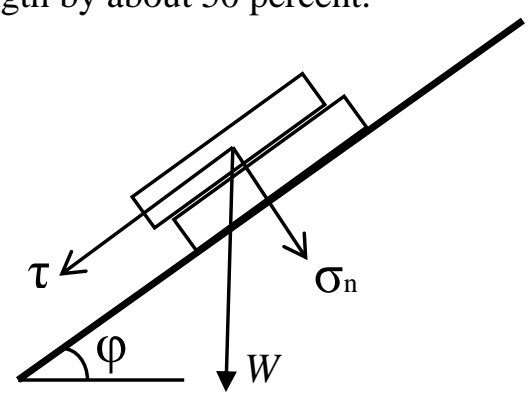

Figure 5-The stress analysis resulting from the weight of the body on the sloping surface that represents the field stress on the discontinuity surface due to the rock mass weight.

Table 2-The results of the tilting test and the predicted shear strength.

\begin{tabular}{|c|c|c|c|}
\hline S. No. & Mean $\varphi$ angle $^{\circ}$ & $\tau$ MPa Eq. 2 & T MPa Eq. 1 \\
\hline Purple sandy shale & 49.98 & 0.1614 & 0.2279 \\
\hline Mudstone & 56.70 & 0.6407 & 0.7334 \\
\hline Sandy marl & 59.60 & 0.5990 & 0.4423 \\
\hline Gypsum & 73.57 & 0.8224 & 0.6763 \\
\hline Mean & 59.96 & 0.5559 & 0.5200 \\
\hline
\end{tabular}

The slake-durability test was conducted to explain the amounts and inequalities of the three claybearing rock samples of purple-sandy shale, mudstone, and sandy marl (Table 3). The results of the test showed that the sandy shale was the most loosened, followed by the claystone, and that the sandy marl rocks are the least slaking ones. This can be caused by a high carbonate percentage in the third type, which increases grain cohesion.

The free swelling of purple sandy shale and sandy marl reveals the same patterns, with values between 4 and 5 percent (Figure-6). Noting that the same swelling occurred during the first hour in these two types of rocks [24], it started to settle rapidly. The explanation for this behavior could be the presence of sand that gave porosity and high permeability to these two types of rocks. which quickly led to water spread through the rocks [24]. Concerning the mudstone rocks mainly composed of chlorite, palygorskite, and montmorillonite, the swelling was gradual until it reached a semi-stable state within two days. The reason for this phenomenon is that the rocks are very compatible with small grains and that they have a porous structure and low permeability.

Such characteristics of durability and swelling explain the tendency of Gercus Formation to disintegrate quickly. The tested samples were disintegrating during the free swelling test, where they were placed in underwater for three months until they reached full disintegration.

Table 3-The results of the slake-durability test for clay-bearing rocks.

\begin{tabular}{|c|c|c|c|c|c|c|c|c|c|c|}
\hline \multirow[b]{2}{*}{ Sample } & \multicolumn{2}{|c|}{ First cycle } & \multicolumn{2}{|c|}{ Second cycle } & \multicolumn{2}{|c|}{ Third cycle } & \multicolumn{2}{|c|}{ Forth cycle } & \multicolumn{2}{|c|}{ Fifth cycle } \\
\hline & $\begin{array}{l}\mathrm{W}_{1} \\
\mathrm{gm}\end{array}$ & $\begin{array}{l}S_{1} \\
\mathrm{gm}\end{array}$ & $\mathrm{W}_{1} \mathrm{gm}$ & $\mathrm{S}_{2} \mathrm{gm}$ & $\begin{array}{l}\mathrm{W}_{1} \\
\mathrm{gm}\end{array}$ & $\mathrm{S}_{3} \mathrm{gm}$ & $\begin{array}{l}\mathrm{W}_{1} \\
\mathrm{gm}\end{array}$ & $\mathrm{S}_{4} \mathrm{gm}$ & $\begin{array}{l}\mathrm{W}_{1} \\
\mathrm{gm}\end{array}$ & $\mathrm{S}_{5} \mathrm{gm}$ \\
\hline Sandy shale & $\begin{array}{l}198 . \\
8\end{array}$ & $\begin{array}{l}178 . \\
9\end{array}$ & 198.8 & 163.8 & 198.8 & 159.1 & 198.8 & 156.6 & 198.8 & 151.1 \\
\hline Slaking & \multicolumn{2}{|l|}{10.01} & \multicolumn{2}{|l|}{17.60} & \multicolumn{2}{|l|}{19.96} & \multicolumn{2}{|l|}{21.23} & \multicolumn{2}{|l|}{24.00} \\
\hline Durability & \multicolumn{2}{|c|}{89.99} & \multicolumn{2}{|l|}{82.40} & \multicolumn{2}{|l|}{80.04} & \multicolumn{2}{|l|}{78.77} & \multicolumn{2}{|l|}{76.00} \\
\hline Mudstone & $\begin{array}{l}440 . \\
5\end{array}$ & $\begin{array}{l}401 . \\
8\end{array}$ & 440.5 & 371.6 & 440.5 & 358.7 & 440.5 & 354.0 & 440.5 & 339.9 \\
\hline Slaking & \multicolumn{2}{|l|}{8.79} & \multicolumn{2}{|l|}{15.64} & \multicolumn{2}{|l|}{18.56} & \multicolumn{2}{|l|}{19.63} & \multicolumn{2}{|l|}{22.83} \\
\hline Durability & \multicolumn{2}{|l|}{91.21} & \multicolumn{2}{|l|}{84.36} & \multicolumn{2}{|l|}{81.44} & \multicolumn{2}{|l|}{80.37} & \multicolumn{2}{|l|}{77.17} \\
\hline Sandy marl & 469. & 433. & 469.3 & 417.6 & 469.3 & 405.1 & 469.3 & 393.7 & 469.3 & 382.4 \\
\hline
\end{tabular}




\begin{tabular}{|l|l|l|l|l|l|l|l|l|l|}
\hline & 3 & 3 & & & & & & & \\
\hline Slaking & 7.67 & 11.02 & 13.68 & 16.11 & 18.52 \\
\hline Durability & 92.33 & 88.98 & 86.32 & 83.89 & 81.48 \\
\hline
\end{tabular}

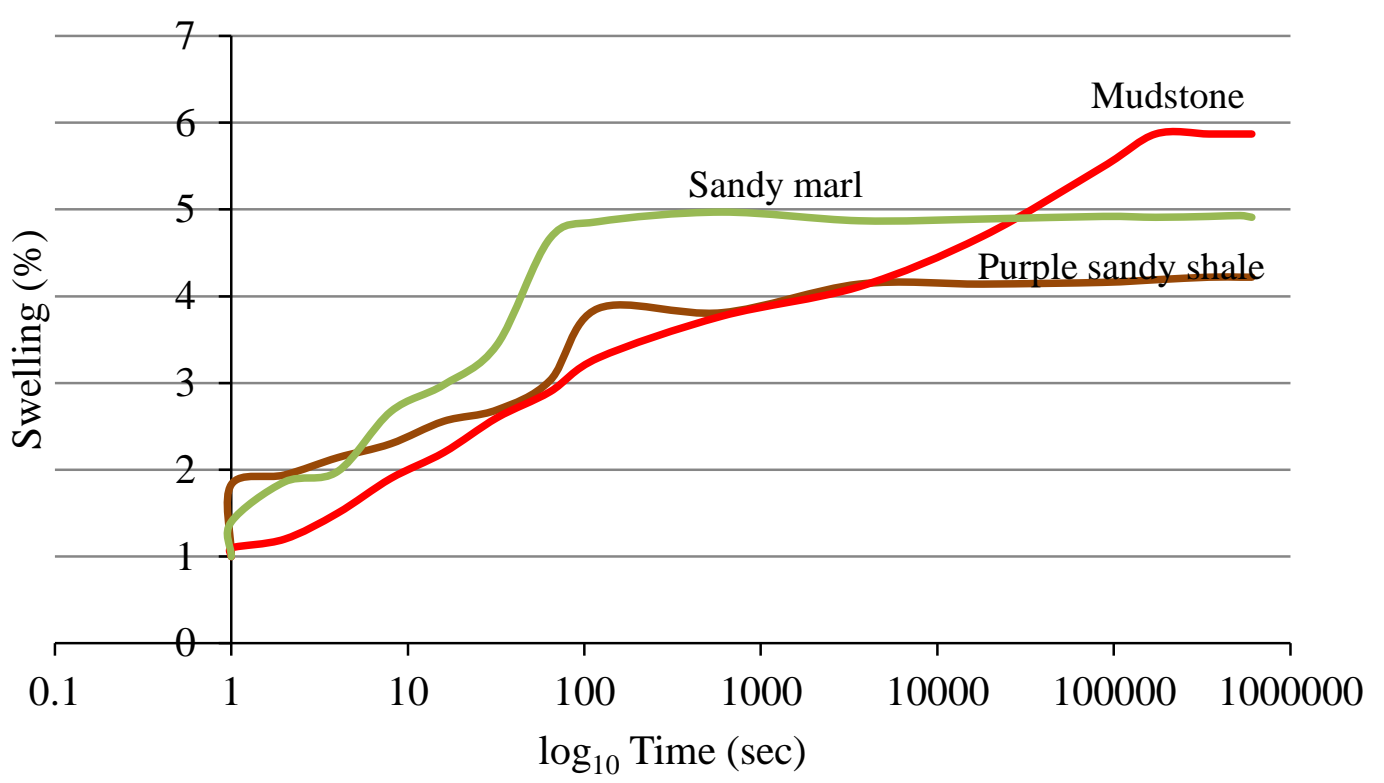

Figure 6-Free swelling of rocks that contain clay minerals.

\section{Conclusions}

The study concludes the necessity of stabilizing the slopes on the edge of the dam reservoir and preventing the arrival of rock crumbs resulting from the erosion of the rocks of the Gercus Formation to the reservoir. The study clarified the possibility of using laboratory tests to show the effects of environmental activities on the fragmentation and erosion of rocks and thus their environmental impact on the reservoir. Measurements of shear strength in this study provided more close results between laboratory testing and the deduced values of rock masses. It is more analogous to the nature of rock mass and mechanical discontinuities to split the rock specimen into two parts rather than cutting it.

\section{Acknowledgment}

The authors of this paper would like to express gratitude to the University of Mosul, Mosul, Iraq for support to complete this work. For much fruitful cooperation on laboratory tests, we thank our colleagues in the Dams and Water Resources Research Center as well as the Department of Civil Engineering - University of Mosul.

\section{References}

1. Fouad, S. F. A. (2015) “Tectonic Map of Iraq, Scale 1 : 1000 000”, Iraqi Bull. Geol. Min., Vol. 11, No. 1, pp. 1-7.

2. Smith, W. C. (1966) "Geologic factors in dam and reservoir planning," Environ. Geol. No. 013.

3. Schleiss, A. J., Franca, M. J., Juez, C. and De Cesare, G. (2016) "Reservoir sedimentation," J. Hydraul. Res., Vol. 54, No. 6, pp. 595-614.

4. Issazadeh, L. and Govay, M. (2014) "Reservoir sediment prediction in Duhok Dam using artificial neural network and conventional methods," Indian J. Fundam. Appl. Life Sci., Vol. 4, pp. 441446.

5. Tran, T. V., Alkema, D., and Hack, R. (2019) "Weathering and deterioration of geotechnical properties in time of groundmasses in a tropical climate," Eng. Geol., Vol. 260, p. 105221, doi: 10.1016/j.enggeo.2019.105221.

6. Hack, H.R.G.K. (2020) "Weathering, erosion and susceptibility to weathering," In: Kanji, M., He, M., Ribeira E Sousa, L. (Eds), Soft Rock Mechanics and Engineering, 1 ed, Ch. 11. Springer Nature Switzerland AG, Cham, Switzerland. ISBN: 9783030294779. DOI: 
10.1007/978303029477-9_11.pp. 291-333.

7. [7] Sissakian, V. K. and Fouad, S. F. A. (2015) "Geological map of Iraq", scale 1: 1000 000, 2012," Iraqi Bull. Geol. Min., Vol. 11, No. 1, pp. 9-16.

8. [8] USGS, (2020) "National Earthquake Information Center," USGS, Box 25046, MS 967, Denver, CO 80225.

9. Jassim, S. Z. and Goff, J. C. (2006) "Geology of Iraq", 1 st. Dolin, Hlavni 2732, Prague and Moravian Museum, Zelny trh 6, Brno, Czech Republic.

10. Barton, N. (1978) "Suggested methods for the quantitative description of discontinuities in rock masses," Int. J. Rock Mech. Min. Sci. Geomech. Abstr., Vol. 16, No. 2, 22 P., doi: 10.1016/01489062(79)91476-1.

11. Bieniaswski, Z. T. "Engineering Rock Mass Classifications." p. 249, 1989.

12. Bigman, R. D. (2001) "Engineering Geology Field Manual," U.S. Dep. Inter. Bur. Reclam., 404 P., doi: 10.1515/9781618119056-018.

13. Liu, Y. and Chen, C. (2007) "A new approach for application of rock mass classification on rock slope stability assessment," Eng. Geol., Vol. 89, pp. 129-143, doi: 10.1016/j.enggeo.2006.09.017.

14. Alejano, L. R. Muralha, J. Ulusay, R. Li, C. C. Pérez-Rey, I. Karakul, H. Chryssanthakis, P. Aydan, Ö. (2018) "ISRM Suggested Method for Determining the Basic Friction Angle of Planar Rock Surfaces by Means of Tilt Tests," Rock Mech. Rock Eng., Vol. 51, No. 12, pp. 3853-3859, doi: 10.1007/s00603-018-1627-6.

15. ISRM, (1979) "Suggested Methods for Determining Water Content, Porosity, Density, Absorption, and Related Properties and Swelling and Slake-Durability Index Properties," in Int. J. Rock Mech. Min. Sci. \& Geomech, Abstr., Vol. 16, No. 2, pp. 151-156.

16. Bieniawski, Z.T. and Bernede, M.J. (1977) "Suggested Methods for Determining the Uniaxial Compressive Strength and Deformability of Rock Materials," Vol. 16, No. 2, pp. 137-141, doi: doi.org/10.1016/0148-9062(79)91450-5.

17. Hoek, E. Carranza-Torres, C. and Corkum, B. (2002) "Hoek-Brown failure criterion-2002 edition," Proc. NARMS-Tac, Vol. 1, No. 1, pp. 267-273.

18. Hoek, E. and Diederichs, M. S. "Empirical estimation of rock mass modulus," Int. J. Rock Mech. Min. Sci., vol. 43, no. 2, pp. 203-215, 2006.

19. Barton, N. and Choubey, V. (1977) "The shear strength of rock joints in theory and practice," Rock Mech., Vol. 10, No. 1, pp. 1-54, doi: 10.1007/BF01261801.

20. Barton, N. (1973) "Review of a new shear strength criterion for rock joints," Eng. Geol., Vol. 7 , No. 4, pp. 287-332.

21. Rahim, I. A. (2018) "Sample type of tilt testing and basic friction angle value for the Crocker formation's fine sandstone of Sabah, Malaysia," ASM Sci. J., Vol. 11, No. Special Issue 3, pp. 215-223.

22. Barton, N. R. (2008) "Shear strength of rockfill, interfaces and rock joints, and their points of contact in rock dump design," Rock Dumps 2008; Aust. Cent. Geomech., No. 1981, pp. 3-18.

23. Bandis, S., Lumsden, A.C. and Barton, N.R. (1981) "Experimental studies of scale effects on shear strength, and deformation of rock joints," Int. J. Rock Mech. Min. Sci. \& Geomech, Abstr., Vol. 18, No. 1, pp. 1-21, https://doi.org/10.1016/0148-9062(81)90262-X.

24. Grindrod, P. Peletier, M. and Takase, H. (1999) "Mechanical interaction between swelling compacted clay and fractured rock, and the leaching of clay colloids," Eng. Geol., Vol. 54, pp. 159-165. 